\title{
Cloning, Expression and Identification by Immunohistochemistry of Humanized Single-Chain Variable Fragment Antibody against Hepatitis C Virus Core Protein
}

\author{
YONG-ZHI LUN ${ }^{1,2, *}$, JUN CHENG ${ }^{2}$, YAN-WEI ZHONG ${ }^{2}$, ZENG-GUO YU1 $^{1}$, QI WANG ${ }^{2}$, \\ FANG WANG and JIE FENG ${ }^{1}$ \\ ${ }^{1}$ Liaoning Provincial University Key Laboratory of Biophysics, Medical College \\ Dalian University, Dalian 116622, China \\ ${ }^{2}$ Institute of Infectious Diseases, Beijing Ditan Hospital, Beijing 100015, China \\ Received 29 April 2010, revised 17 December 2010, accepted 14 January 2011
}

\begin{abstract}
Expression of single-chain variable fragment ( $\mathrm{scFv}$ ) antibodies on the surface of bacteriophage is widely used to prepare antibodies with pre-defined specificities. A phage antibody library containing the gene for $\mathrm{scFv}$ antibody against Hepatitis $\mathrm{C}$ virus core protein was panned with core protein immobilized on microtiter plate wells. After five rounds of panning 60 phage clones specific to core protein were obtained and one selected clone was sequenced. It was found that the specifically detected antigen consists of 774bp and is capable of encoding 257 amino acids in the patients but not in healthy persons.
\end{abstract}

K e y w ord s: Hepatitis C virus; core protein; phage display; single-chain variable fragment antibody

Abbreviations: HRP, horseradish peroxidase; HCV, Hepatitis C virus; HCV core protein scFv antibody, scFv antibody against HCV core protein; MAb, monoclonal antibody; scFv, single-chain variable fragment.

\section{Introduction}

Hepatitis $\mathrm{C}$ virus (HCV) was first described in 1989 as the putative viral agent of non-A non-B hepatitis. An estimated 170 million people are infected with HCV worldwide (Armstrong, 2003; Stoll-Keller et al., 2009). HCV is a member of the Flaviviridae family and has been recognized as the major causative agent of chronic liver disease, including chronic active hepatitis, cirrhosis and hepatocellular carcinoma (Di Bisceglie, 2000). It has recently been suggested that HCV core protein suppresses the antiviral cytotoxic T-lymphocyte response by interacting with the $\mathrm{C} 1 \mathrm{q}$ complement receptor, thereby playing a key role in the induction and maintenance of chronic $\mathrm{HCV}$ infection and liver damage (Kittlesen et al., 2000; Large et al., 1999). The presence of serum HCV core protein is associated with active $\mathrm{HCV}$ viremia, and its detection is now used for clinical evaluations (Dickson et al., 1999; Tanaka et al., 2000). In addition, $\mathrm{HCV}$ core protein is highly conserved among the various HCV genotypes (Houghton et al., 1991) and elicits a rapid Antibody response after the onset of the disease. Thus, antibody responses to HCV core protein may be considered to confer protection against $\mathrm{HCV}$ infection regardless of viral subtypes. The monoclonal antibodies $(\mathrm{McAb})$ of $\mathrm{HCV}$ core protein could passively conduce to prevent $\mathrm{HCV}$ infection. However, the production periodicity of McAb made by hybridoma technique is relatively long. In addition, clinical testing has shown that murine monoclonal antibodies may evoke human anti-mouse antibody response. Phage display technology offers a means of cloning human anti-HCV antibodies coding gene of a defined specificity that may have potential therapeutic use (Canaan-Haden et al., 1995). We now utilize a semi-synthetic human single-chain Fv antibody library and solid-phase bound hepatitis $\mathrm{C}$ virus core protein to screen out the phage display antibody that recognizes the HCV core protein (Zhong et al., 2001), using HCV core protein as the immobilized antigen and proceeding immunohistochemistry.

\footnotetext{
* Corresponding author: Yong-Zhi Lun; e-mail: lunyz@163.com
} 


\section{Experimental}

\section{Materials and Methods}

Materials. A recombinant $\mathrm{HCV}$ core protein from Virostat (USA) was employed. A human scFv antibody phage library in which the genes encoding VL and VH were amplified by PCR with degenerate primers and connected with a glycine linker $\left[\left(\mathrm{Gly}_{4} \mathrm{Ser}\right)_{3}\right]$, was purchased from Novagen (USA). M13K07 phage was employed as helper (Pharmacia).

Phagemids rescue. To rescue phagemids from the library, $5 \mathrm{ml}$ of $2 \times \mathrm{TY}$ broth containing $100 \mathrm{mg} / \mathrm{ml}$ ampicillin and $1 \%$ glucose $(2 \times$ TY-AMP-GLU) was inoculated with $10 \mu \mathrm{l}$ of Escherichia coli TG1 taken from the library stock and grown for $3 \mathrm{hrs}$ at $37^{\circ} \mathrm{C}$. The bacteria were spun down, resuspended in $50 \mathrm{ml}$ of $2 \times \mathrm{TY}$ broth containing $100 \mathrm{mg} / \mathrm{ml}$ ampicillin $(2 \times \mathrm{TY}-\mathrm{AMP})$, and shaken until $\mathrm{A}_{600}$ reached 0.5. The bacteria were inoculated with M13K07 phage $\left(1 \times 10^{10} \mathrm{PFU}\right)$ and incubated for $30 \mathrm{mins}$ at $37^{\circ} \mathrm{C}$ without shaking. After pelleting the cells were resuspended in $200 \mathrm{ml}$ of $2 \times$ TY broth containing $100 \mathrm{mg} / \mathrm{ml} \mathrm{ampi-}$ cillin and $25 \mathrm{mg} / \mathrm{ml}$ kanamycin $(2 \times$ TY-AMP-KAN), and shaken for $12 \mathrm{hrs}$ at $37^{\circ} \mathrm{C}$. Phage particles were purified and concentrated using polyethylene glycol and resuspended in $2 \mathrm{ml}$ of distilled water.

Screening of HCV core protein $\mathrm{ScFv}$ antibody clones. Delta surface plates (Nalge Nunclon International, Denmark) were coated with $1 \mathrm{ml}$ of $\mathrm{HCV}$ core protein $(80 \mu \mathrm{g} / \mathrm{ml})$ per well in a coating buffer (50 mmol/1 carbonate/bicarbonate $\mathrm{pH}$ 9.6) overnight at $4^{\circ} \mathrm{C}$. After washing with Tris-borate-saline (TBS), the plates were incubated in 2\% BSA in PBS for $2 \mathrm{hrs}$ at $37^{\circ} \mathrm{C}$ (blocking). The washing was repeated and the purified phage in $2 \%$ BSA $(1 \mathrm{ml})$ was added. The plates were rotated gently for 10 mins, left undisturbed for 90 mins at $37^{\circ} \mathrm{C}$, and washed 20 times with PBS with $0.1 \%$ Tween 20 and 20 times with PBS. The bound phage particles were eluted from the plates with $1 \mathrm{ml}$ of $100 \mathrm{mmol} / 1$ triethylamine per plate. The phage-containing elutate was immediately neutralized with $0.5 \mathrm{ml}$ of $1.0 \mathrm{~mol} / 1 \mathrm{Tris}-\mathrm{HCl} \mathrm{pH} 7.4$ and stored at $4^{\circ} \mathrm{C}$. The phage was used to infect $10 \mathrm{ml}$ of log-phase E. coli TG1 plated on TYE-AMP-GLU plates and grown overnight at $37^{\circ} \mathrm{C}$. The colonies were picked up into $2 \mathrm{ml}$ of TYE-AMP-GLU per colony with $30 \%$ $(\mathrm{v} / \mathrm{v})$ glycerol and stored at $-20^{\circ} \mathrm{C}$. The panning (amplification-adsorption-elution) was repeated 5 times, and 30 phage clones were picked up randomly from well-isolated colonies on the top-agar plates. Each clone was grown in $400 \mu 1$ of $2 \times$ TY-AMP-GLU at $37^{\circ} \mathrm{C}$ overnight. Aliquots $(20 \mu \mathrm{l})$ of each clone were transferred to $400 \mu 1$ of $2 \times$ TY-AMP and further cultured until $\mathrm{A}_{600}$ reached 0.5. After adding a helper phage the cultures were incubated at $30^{\circ} \mathrm{C}$ overnight. To collect samples for ELISA the supernatants after centrifugation at 12,000 r.p.m. for $1 \mathrm{~min}$ at $4^{\circ} \mathrm{C}$ were saved.

Identification of phage clones. Wells of 96-wellplates were coated overnight with $8 \mu \mathrm{g} \mathrm{HCV}$ core protein in $100 \mu \mathrm{l}$ of coating buffer per well. After blocking for $2 \mathrm{hrs}$ at $37^{\circ} \mathrm{C} 50 \mu \mathrm{l}$ aliquots of culture supernatants and $50 \mu \mathrm{l}$ of $2 \%$ BSA were added per well for $1 \mathrm{hr}$ at $37^{\circ} \mathrm{C}$. After washing with $0.05 \%$ Tween 20 in PBS a 1/5000 dilution of horseradish peroxidase (HRP)-labeled anti-M13 secondary antibody was added for $1 \mathrm{hr}$ at $37^{\circ} \mathrm{C}$. The plates were washed with $0.05 \%$ Tween 20 -PBS and a tetramethylbenzidine solution was added for 10 mins at $37^{\circ} \mathrm{C}$. The reaction was stopped with $\mathrm{H}_{2} \mathrm{SO}_{4}$ and $\mathrm{A}_{450}$ was read.

ELISA. Wells of 96-well-plates were coated overnight with $8 \mu \mathrm{g} \mathrm{HCV}$ core protein per well in the coating buffer. After blocking $100 \mu \mathrm{l}$ aliquots of diluted (1:50) culture supernatants were added per well for $1 \mathrm{hr}$ at $37^{\circ} \mathrm{C}$. The plates were washed and loaded with the secondary antibody as described above. M13K07 phage served as negative control.

DNA sequencing. Plasmid DNA was prepared from the culture of a selected positive clone using Wizard Plus Minipreps DNA Purification System (Promega) and sequenced in an ABI3700 automated DNA sequencer (Perkin Elmer).

Expression of soluble $\mathrm{HCV}$ core protein scFv antibody in E. coli. To express the scFv antibody in soluble E-tagged form the selected clone was subcloned into the pCANTAB5E expression vector. Restriction digestion and subsequent $1 \%$ agarose gel electrophoresis confirmed the identity of the recombinant pCANTAB5E-scFv vector. Competent E. coli XL1-Blue was transformed with pCANTAB5E-scFv and induced with IPTG for $20 \mathrm{hrs}$. The culture was centrifuged at 10,000 r.p.m. and the supernatant was subjected to SDS-PAGE and Western blot analysis.

Western blot analysis. The culture supernatant was diluted 1:1 with $2 \times$ SDS loading buffer, heated at $100^{\circ} \mathrm{C}$ for $10 \mathrm{mins}$, briefly centrifuged again, and $20 \mu 1$ of the supernatant was used for SDS-PAGE. After the run the gel was blotted onto a PVDF membrane (Millipore). The blot was blocked with 5\% non-fat dry milk for $2 \mathrm{hrs}$, incubated with an antiE-tag MAb for $1.5 \mathrm{hr}$ and with a secondary HRP-goat anti-mouse IgG antibody for another $1 \mathrm{hr}$, and stained with $\mathrm{DAB}$ and hydrogen peroxide.

Immunohistochemistry. Paraffin-embedded liver tissue slices from patients with positive anti-HCV antibodies and HCV-RNA. were examined. After deactivating endogenous hyperoxidase the slices were submersed in a methanol solution (should be defined) with $0.5 \%$ hydrogen peroxide at room temperature for 50 mins, washed with PBS 3 times, and kept in 5\% 
Table I

The complementarity-determining regions (CDRs) and framework regions (FRs) of deduced amino acids sequence of $\mathrm{ScFv}$ against $\mathrm{HCV}$ core protein

\begin{tabular}{|l|l|c|c|c|c|c|c|}
\hline & CDR1 & \multicolumn{1}{c|}{ CDR2 } & CDR3 & \multicolumn{1}{c|}{ FR1 } & \multicolumn{1}{c|}{ FR2 } & \multicolumn{1}{c|}{ FR3 } & FR4 \\
\hline H chain & $\begin{array}{l}\text { GFTFSSY- } \\
\text { AMS }\end{array}$ & $\begin{array}{l}\text { AISGSGGST- } \\
\text { YYADSVKG }\end{array}$ & TRTKRF & $\begin{array}{l}\text { EVQLVESGGGLV- } \\
\text { RPGGSLRLSCAAS }\end{array}$ & $\begin{array}{l}\text { WVRQAPGKGL- } \\
\text { EWVS }\end{array}$ & $\begin{array}{l}\text { RFTISRDNSKNTL- } \\
\text { YLQMNSLRAEDT } \\
\text {-AVYYCAR }\end{array}$ & WGQGALVTVSR \\
\hline L chain & $\begin{array}{l}\text { CQGDSL- } \\
\text { RSYYAS }\end{array}$ & GKNNRPS & $\begin{array}{l}\text { NSPDSSG- } \\
\text { NHVV }\end{array}$ & $\begin{array}{l}\text { SELTQDPAVS- } \\
\text { VALGQTVRIT }\end{array}$ & $\begin{array}{l}\text { WYQQKPGQAP- } \\
\text { VLVIY }\end{array}$ & $\begin{array}{l}\text { GIPDRFSGSSSGN- } \\
\text { TASLTITGAQAED- } \\
\text { EADYYC }\end{array}$ & FGGGTKLTVLG \\
\hline
\end{tabular}

BSA overnight at $4^{\circ} \mathrm{C}$. Then the slices were incubated with the scFv antibody diluted $1: 100$ for $1 \mathrm{hr}$ at $37^{\circ} \mathrm{C}$ and overnight at $4^{\circ} \mathrm{C}$. A sheep HRP-anti-M13 antibody diluted 1:200 was dropped on tissue preparations and left to react for $40 \mathrm{~min}$ at $37^{\circ} \mathrm{C}$. The preparations were washed 3 times with PBS, a few drops of a DAB solution $(9 \mathrm{mg}$ DAB, $13.5 \mathrm{ml} 0.01 \mathrm{M}$ Tris- $\mathrm{HCl}$

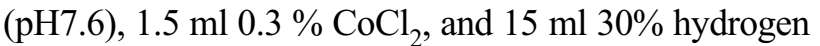
peroxide) were added. After 10 min at room temperature the preparations were washed with PBS 3 times and $1 \%$ haematin was used to stain the cell nucleus. After a standard dehydratation procedure the preparations were observed under microscope. Negative controls consisted of PBS instead of the scFv antibody and liver tissue preparations from healthy persons.

\section{Results}

Identification of $\mathrm{HCV}$ core protein scFv-positive clones. After five rounds of panning (amplificationabsorption-elution) 60 clones were picked up and tested for $\mathrm{HCV}$ core protein $\mathrm{scFv}$ antibody by ELISA.

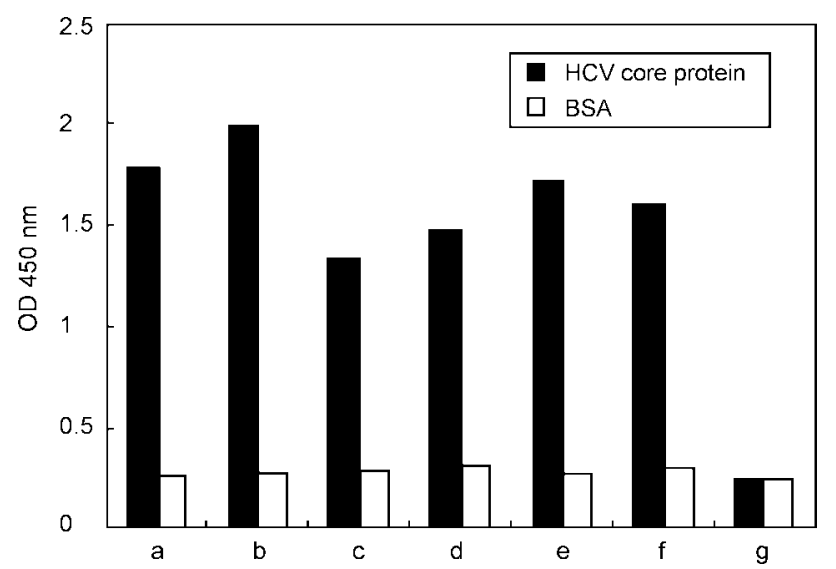

Fig. 1. Identification of positive clones. The binding activities of the phage antibodies from six clones infected by bound phage particles to coated $8 \mu \mathrm{g} \mathrm{HCV}$ core protein and $20 \mu \mathrm{g}$ bovine serum albumin.

a-f: positive clones' culture supernatant with $\mathrm{scFv}$ antibody against HCV core protein; g: helper M13K07 instead of phage antibodies, used as negative.
Twenty of these were found positive. Six of these showed a low cross-reaction with BSA (Fig. 1). One positive clone with the highest reaction with $\mathrm{HCV}$ core protein and the lowest reaction one with BSA was chosen for a confirmatory test with restriction digestion. The digestion with NcoI and NotI and subsequent gel electrophoresis proved the presence of a $774 \mathrm{bp}$ insert corresponding to the scFv antibody gene (Fig. 2).

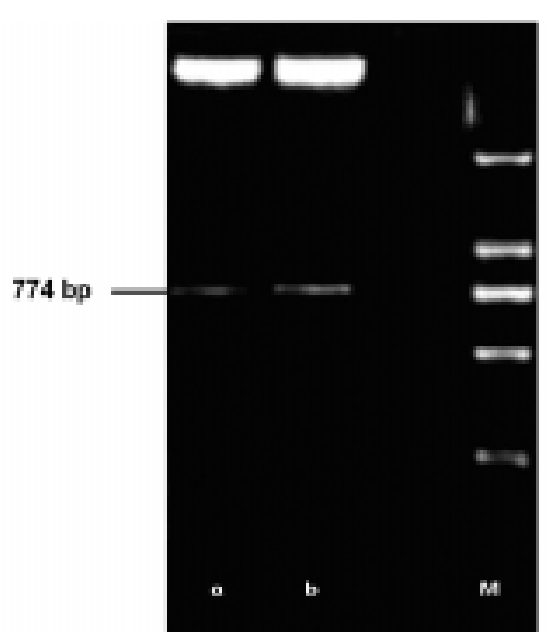

Fig. 2. Restriction map of plasmid DNA carrying HCV core protein $\mathrm{scFv}$ gene prepared from a single positive clone by NcoI/NotI digestion.

a, b: DNA fragment with $\mathrm{HCV}$ core protein $\mathrm{scFv}$ gene; M: DNA Marker DL2000 (Takara Co., Japan)

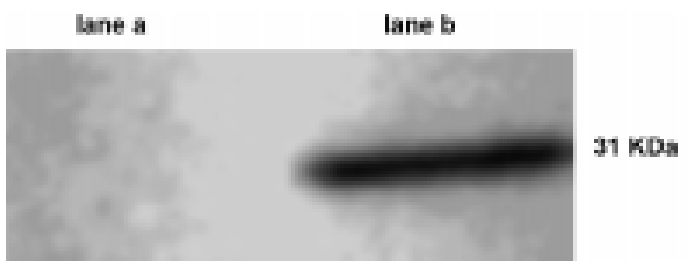

Fig. 3. Western blot analysis of the supernate protein derived from induced and non-induced $E$. coli XL1-Blue transformed by expression vector.

Supernate protein from non-induced E. coli XL1-Blue transformed with pCANTAB5E-HCV core protein-scFv (lane a) and supernate protein from induced E. coli XL1-Blue transformed with pCANTAB5E-HCV core protein-scFv (lane b). 

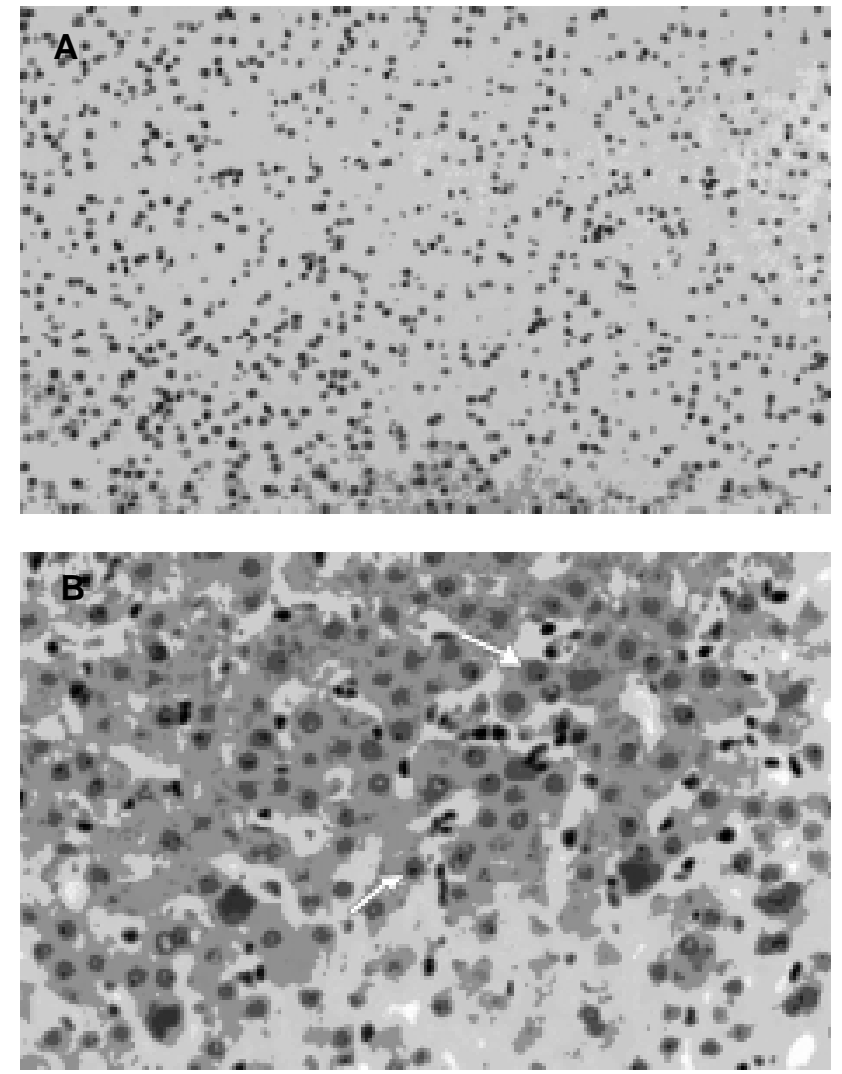

Fig. 4. Immunostaining of $\mathrm{HCV}$ core protein of different sections from liver tissues of healthy persons and patients with chronic hepatitis $\mathrm{C}$, self-made anti-HCV core protein single chain antibodies used as primary antibody.

A: Immunohistochemistry of HCV core protein of liver tissue from health person; B: Immunohistochemistry of $\mathrm{HCV}$ core protein of liver tissue from patients with chronic hepatitis $\mathrm{C}$, core protein was detected in the cytoplasm of some liver cells (arrowhead pointing).

Sequencing of $\mathrm{HCV}$ core protein $\mathrm{ScFv}$ gene. The nucleotide sequence of the selected clone was determined and submitted to GenBank (Acc. No AF271150). The corresponding amino acid sequence was deduced and complementarity-determining regions and framework regions were located according to the Kabat database (Table I).

Expression of $\mathrm{HCV}$ core protein $\mathrm{scFv}$ in $E$. coli. The HCV core protein $\mathrm{scFv}$ antibody was expressed in E. coli and confirmed by Western blot analysis (Fig. 3). A negative control consisting of E. coli infected with empty vector did not show any specific protein. These results indicated that the soluble form of human HCV core protein scFv antibody was successfully expressed in this system.

Immunostaining of $\mathrm{HCV}$ core protein of liver tissue sections. Immunostaining of sections of liver tissues from and 17 patients with chronic hepatitis $\mathrm{C}$ and healthy persons gave positive results in the former but not latter group (Fig. 4). HCV core protein was mainly located in the cytomembrane of the hepatocytes.

\section{Discussion}

The mature HCV protein is located in the cytoplasm of infected cells, in close vicinity to the perinuclear membranes and the endoplasmic reticulum, where it polymerizes in the presence of genomic RNA to form viral capsids (Reed and Rice, 2000). The $\mathrm{HCV}$ core protein is highly antigenic, induces specific cellular and humoral responses, and probably plays a pivotal role in the pathogenesis of $\mathrm{HCV}$ infection (Lai and Ware, 2000; Nelson et al., 1997). The availability of an anti-HCV core protein humanized scFv antibody allowed the development of an ELISA to detect $\mathrm{HCV}$ core antigen in peripheral blood of patients with HCV (Aoyagi et al., 1999). The major neutralizing epitope of $\mathrm{HCV}$ core protein lies within the first 45 aa of the protein, the major antigenic segment of core recognized both by murine and human antibodies. Noticeable, the recognized epitope (29-37: QIVGGVYLL) has an unusual preponderance of hydrophobic residues, some of which are buried in a small hydrophobic core in the nuclear magnetic resonance structure of the peptide in solution, suggesting that the antibody may induce a structural rearrangement upon recognition (Menez et al., 2003).

Phage libraries are a powerful tool for the selection of antibodies of important and useful specificities, particularly for humanized $\mathrm{scFv}$ antibodies (Marks et al., 1991; Hoogenboom et al., 1998; Lamarre and Talbot, 1997; Rondon and Marasco, 1997). It has many advantages. First, it is the only method to get specific antibody by passing the immunization step. It can mimic the maturation process of human antibody in vivo, so that it is possible to obtain a high affinity antibody from this selection. Second, a scFv antibody consisting of antigen-binding domains of heavy and light chain regions of immunoglobin connected by a flexible peptide linker is a small-size molecule compared with the full-length antibody. If an antibody library of human origin is used, the selected antibody is most suitable to human administration and is potentially applicable to clinical diagnosis and treatment of both infectious disease and cancer. Finally, as it contains no Fc fragment, its background in immunohistological study is very low. In contrast, a MAb against the recombinant $\mathrm{HCV}$ core protein prepared from hybridomas is of murine origin and hence immunogenic if used systemically in humans (Songsivilai et al., 1996). In order to overcome the disadvantages of an intact MAb applied in vivo and to offer an antibody with a stable genetic source, soluble $\mathrm{scFv}$ antibodies are currently generated by advanced recombinant phage antibody technique, which may provide novel targeting vehicle for diagnosis and treatment of diseases. 
In this study, we succeeded in cloning the HCV core protein $\mathrm{scFv}$ gene by means of the phage display library technique. The cloned gene was sequenced and expressed in E. coli. These results illustrate the feasibility of using the antibody-engineering technology that may prove useful in the future for diagnostics and therapy of hepatitis $\mathrm{C}$ infection.

\section{Literature}

Aoyagi K., C. Ohue and K. Iida. 1999. Development of a simple and highly sensitive enzyme immunoassay for hepatitis $\mathrm{C}$ virus core antigen. J. Clin. Microbiol. 37: 1802-1808.

Armstrong G.L. 2003. Commentary: modeling the epidemiology of hepatitis $\mathrm{C}$ and its complications. Int. J. Epidemiol. 32: $725-726$.

Canaan-Haden L., M. Ayala and M.E. Fernandez-de-Cossio. 1995. Purification and application of a single-chain Fv antibody fragment specific to hepatitis B virus surface antigen. Biotechniques 19: 606-612.

Di Bisceglie A.M. 2000. Natural history of hepatitis C: its impact on clinical management. Hepatology 31: 1014-1018.

Dickson R.C., M. Mizokami and E. Orito. 1999. Quantification of serum HCV core antigen by a fluorescent enzyme immunoassay in liver transplant recipients with recurrent hepatitis C: clinical and virologic implications. Transplantation. 68: 1512.

Hoogenboom H.R., A.P. de Bruine and S.E. Hufton. 1998. Anti-body phage display technology and its applications. Immunotechnology 4: 1-20.

Houghton M., A. Weiner and J. Han. 1991. Molecular biology of the hepatitis $\mathrm{C}$ virus: implications for diagnosis, development, and control of viral disease. Hepatology 14: 381.

Kittlesen D.J., K.A. Chianese-Bullock and Z.Q. Yao. 2000. Interaction between complement receptor $\mathrm{gClqR}$ and hepatitis $\mathrm{C}$ virus core protein inhibits T-lymphocyte proliferation. J. Clin. Investig. 106: 1239-1249.
Hagedorn C.H. and C.M. Rice. 2000. The hepatitis $C$ viruses. Springer-Verlag KG Berlin, Germany.

Lamarre A. and P.J. Talbot. 1997. Characterization of phagedisplayed recombinant anti-idiotypic antibody fragments against coronavirus neutralizing monoclonal antibodies. Viral. Immunol. 10: $175-182$.

Large M.K., D.J. Kittlesen and Y.S. Hahn. 1999. Suppression of host immune response by the core protein of hepatitis $\mathrm{C}$ virus: possible implications for hepatitis $\mathrm{C}$ virus persistence. J. Immunol. 162: 931-938.

Marks J.D., H.R. Hoogenboom and T.P. Bonnert. 1991. Byimmunization human antibodies from V-gene libraries displayed on phage. J. Mol. Biol. 222: 581-597.

Menez R., M. Bossus and B.H. Muller. 2003. Crystal structure of a hydrophobic immunodominant antigenic site on hepatitis $\mathrm{C}$ virus core protein complexed to monoclonal antibody 19D9D6. J. Immunol. 170: 1917-1924.

Nelson D.R., C.G. Marousis and G.L. Davis. 1997. The role of hepatitis $\mathrm{C}$ virus-specific cytotoxic lymphocytes in chronic hepatitis C. J. Immunol. 158: 1473-1481.

Reed K.E. and C.M. Rice. 2000. Overview of hepatitis C virus genome stucture, polyprotein processing, and protein properties. Curr. Top. Microbiol. Immunol. 242: 55-84.

Rondon U. and W.A. Marasco. 1997. Intracellular antibodies (intrabodies) for gene therapy of infectious disease. Annu. Rev. Microbiol. 51: 257-283.

Songsivilai S., T. Dharakul and R. Kunkitti. 1996. Molecular cloning and expression of hepatitis $\mathrm{C}$ virus core protein and production of monoclonal antibodies to the recombinant protein. Asian Pac J Allergy Immunol. 14: 31-41.

Stoll-Keller F., H. Barth and S. Fafi-Kremer. 2009. Development of hepatitis $\mathrm{C}$ virus vaccines: challenges and progress. Expert Rev. Vaccines 8: 333-345.

Tanaka E., C. Ohue and K. Aoyagi. 2000. Evaluation of a new enzyme immunoassay for hepatitis $\mathrm{C}$ virus (HCV) ore antigen with clinical sensitivity approximating that of genomic amplification of HCV RNA. Hepatology 32: 388.

Zhong Y., J. Cheng and S. Shi. 2001. Screening and characterization of human phage antibody to hepatitis $\mathrm{C}$ core antigen (in Chinese). Zhonghua Gan Zang Bing Za Zhi 9: 217-219. 